PROCEDIA

Studi Kasus dan Intervensi Psikologi

ISSN:2302-1462

Volume 7(1) 25-36, Januari 2019

DOI: $10.22219 /$ procedia.v7i1.12978

\title{
Konseling kelompok Realitas untuk menurunkan stres pada ibu dengan anak berkebutuhan khusus
}

Ade Ayu Harisdiane Putri, Universitas Muhammadiyah Malang, Malang, Indonesia

Korespondonesi:

Ade Ayu Harisdiane Putri, Universitas Muhammadiyah Malang, e-mail:ayudianeputri@gmail.com

Riwayat artikel
Naskah diterima:
$07 / 11 / 2018$
Revisi diterima:
30/11/2018
Naskah disetujui:
02/12/2018

\begin{abstract}
Abstrak
Subjek dalam kasus ini adalah ibu yang memiliki anak berkebutuhan khusus yang berjumlah 5 orang dengan rentangan usia antara 37-56 tahun. Metode asesmen yang digunakan adalah wawancara, observasi parental stress scale dan subjective units of distress scale. Didapati bahwa Subjek mengalami V15.89 (Z91.89) other personal risk factor dengan permasalahan stress ibu yang memiliki anak berkebutuhan khusus. Hal ini menjadikan kelima anggota kelompok menjadi pesimis dengan masa depan anak, merasa mengeluarkan energi dan waktu yang banyak untuk mendampingi anak berkebutuhan khusus dan kebutuhan lain yang dapat membuat anak lebih baik dalam pelajaran ataupun interaksi dengan orang lain. Intervensi yang diberikan adalah konseling kelompok realitas yang dilakukan selama 6 sesi. Hasil intervensi didapatkan bahwa dengan konseling kelompok realitas dapat menurunkan tingkat stres ibu yang memiliki anak berkebutuhan khusus. Kata kunci: Konseling kelompok realitas, stres, anak berkebutuhan khusus, intervensi
\end{abstract}

\section{Latar Belakang}

Memiliki anak ialah dambaan semua orang tua. Orang tua mempunyai tugas yang besar untuk mendukung tumbuh kembang anak dengan pola asuh yang tepat. Orang tua ialah individu yang mendorong semua aspek pertumbuhan anak, memelihara, melindungi dan menuntun kehidupan yang lebih baru melalui program - program perkembangan yang baik. Orang tua memiliki tugas dan juga tanggung jawab yang besar untuk mendukung tumbuh kembang anak.

Pada kenyataannya tidak semua orang tua memiliki anak dengan perkembangan normal. Beberapa orang tua memiliki anak dengan permasalahan yang berbeda-beda. Hal ini tentu juga berimbas dengan cara pola asuh orang tua. Mengasuh anak dengan kebutuhan khusus bukanlah hal yang mudah. Mengasuh anak berkebutuhan khusus membuat orang tua stres 
dalam menjalaninya karena seringkali memiliki tingkat kesulitan yang lebih dibandingkan dengan anak dengan perkembangan normal. Bahkan tingkat stres orang tua yang memiliki anak berkebutuhan khusus secara signifikan lebih tinggi daripada orang tua dengan anak normal pada umumnya (Ritzema \& Sladeczek, 2011).

Tuntunan yang harus dipenuhi orang tua dengan anak berkebutuhan khusus ialah menyediakan transportasi, memberikan perhatian lebih, energi yang lebih daripada merawat anak dengan perkembangan normal, kebutuhan anak terkait makanan diet atau juga jika diperlukan menggunakan terapi khusus atau mendatangi profesional untuk memperoleh pelayanan medis maupun edukasi mengenai anak-anak. Dengan adanya berbagai macam yang dibutuhkan untuk anak berkebutuhan khusus tidak menutup kemungkinan akan bertambahnya beban finansial (Martin \& Corlbert, 1997). Banyaknya tuntunan dan kebutuhan yang dihadapi oleh orang tua menjadi tantangan sendiri untuk ibu dan harus dapat diatasi dengan baik. Beberapa anak yang memiliki penanganan khusus, keterlambatan perkembangan membuat orang tua menghadapi tantangan yang lebih besar dalam mendidik anaknya.

Pada asesmen awal yang telah dilakukan kepada lima Subjek intervensi, ditemukan bahwa secara garis besar mereka mengalami keadaan stres karena memiliki anak berkebutuhan khusus. Subjek merupakan ibu yang memiliki anak dengan kebutuhan khusus. Kelima ibu ini merasa stres dalam melakukan pola asuh dengan anak yang berbeda perlakuannya dengan anak pada umumnya. Kelima Subjek selalu melihat masa lalu saat mengetahui jika memiliki anak berkebutuhan khusus karena anak sebelumnya sama seperti anak lainnya dengan perkembangan yang normal. Stres didefinisikan sebagai reaksi terhadap lingkungan saat terjadinya perubahan yang besar didalam hidup (Berry \& Jones, 1995). Stres memiliki arti sebagai hubungan antara seseorang dengan lingkungan yang dinilai membebani kehidupan seseorang.

Konseling realitas menjadi pilihan intervensi yang dinilai sesuai untuk mengatasi masalah ini. Terapi atau konseling realitas merupakan suatu sistem yang difokuskan pada tingkah laku sekarang (Palmer, 2013). Penekanan utama dalam intervensi dengan konseling realitas adalah bahwa terlepas dari apa yang terjadi pada individu, apa yang mungkin telah dikerjakan, atau bagaimana kebutuhan individu telah dilanggar di masa lalu, setiap individu tetap bisa mengevaluasi kembali realitas terkini dan memilih perilaku yang akan membantu memuaskan kebutuhan secara efektif di masa kini dan di masa depan (Bradley, 2014). Konseling realita dalam penelitian sebelumnya memberi hasil yang positif dalam mengatasi stres yang dialami oleh individu agar melihat realitas kehidupan yang lebih baik (Farmani, Taghavi, Fatemi, \& Safavi, 2015).

\section{Metode Asesmen}

Asesmen untuk penegakan diagnosa masalah kelima Subjek dilakukan melalui serangkaian metode, yaitu wawancara, observasi dan pengisian skala. Wawancara dilakukan untuk memperoleh informasi lebih mendalam tentang permasalahan yang dialami Subjek. Observasi dilakukan untuk memperkuat data yang diperoleh dari hasil wawancara. Skala yang digunakan adalah skala parental stress scale untuk melakukan screening awal dan subjective units of distress scale yang digunakan pada tiap sesi untuk mengukur tingkat stress yang dimiliki masing-masing anggota kelompok.

\section{Presentasi Kasus}

Partisipan pada kasus ini adalah lima orang. Usia partisipan berkisar dari 37-56 tahun. Semua partisipan berdomisili di kota Malang dan memiliki dua orang anak, anak kedua ialah anak yang memerlukan penanganan secara khusus. Subjek 1 (EN) Subjek ialah seorang ibu berusia 40 tahun yang memiliki anak berkebutuhan khusus. Anak berkebutuhan khusus ini ialah anak kedua. Anak pertama Subjek normal seperti anak pada umumnya. Menurut Subjek saat 
kehamilannya Subjek lebih sering muntah-muntah dan saat melahirkan mengalami pendarahan. Anak Subjek mengalami down syndrome yang sekarang berusia 10 tahun. Saat balita Subjek sudah berfikir yang negatif, bagaimana mengenai masa depan anak. Memikirkan jauh ke depan, apakah anak bisa sukses. Karena hal itu juga terkadang membuat ia lebih sering marah di rumah. Terlebih anaknya sekarang sudah sekolah dasar tetapi sangat berbeda dengan anak seusianya. Subjek kesulitan dalam pola asuh dan merasa bahwa hampir satu hari waktu dihabiskan untuk anak. Jika tidak dengan anak, Subjek khawatir tetapi jika dengan anak terus Subjek terkadang suka geregetan sendiri karena anaknya yang tidak bisa menuruti keinginannya. Subjek merasa lebih emosional ketika merawat anak kedua. Hal ini juga berimbas ketika sedang mengajak jalan anaknya ke sebuah tempat perbelanjaan, karena anak Subjek banyak tanya dan selalu ingin memegang barang-barang ada anak muda yang bisik-bisik kepada ibunya sambil menunjuk anak Subjek. Awalnya Subjek tidak merespon tetapi lama kelamaan Subjek merasa tidak nyaman dan langsung mendatangi ibu dari anak muda tersebut dan mengatakan jangan menunjuk anaknya dan ia mengatakan bahwa memang anaknya berkebutuhan khusus. Ia juga merasa tidak bebas melakukan apa yang ia lakukan seperti jalan-jalan karena orang - orang akan membicarakan anaknya. Subjek merasa dirinya mungkin terlalu banyak pikiran sehingga cepat emosional. Subjek mendapati skor 50 untuk parental stress scale dengan kategori sedang.

Subjek 2 (DI) Subjek ialah seorang ibu berusia 39 tahun yang memiliki anak berkebutuhan khusus. Anak berkebutuhan khusus ini ialah anak kedua yang berusia 7 tahun. Anak pertama Subjek normal seperti anak pada umumnya. Subjek merasa disaat hamil tidak ada kejadian yang membuatnya berfikir akan mempunyai anak berkebutuhan khusus. Saat sudah berusia 4 tahun ibu merasakan hal yang janggal dari anaknya. Awalnya ibu mengira anaknya memiliki rasa ingin tau yang tinggi tetapi lama kelamaan anaknya tidak bisa diam selalu ingin memegang benda atau menyentuh barang-barang yang ada disekitarnya. Saat memasuki taman kanak-kanak, Subjek memasukkan ke TK SLB karena takut anaknya mengganggu jika dimasukkan di sekolah umum.

Subjek mengatakan anaknya lambat dalam membaca dan menulis, ketika ditanya juga tidak dapat menyampaikan jawaban dengan benar. Anak lebih suka loncat-loncatan dan tidak bisa diam. Anak Subjek mengalami gangguan ADHD ringan. Subjek merasa malu karena jika ditanyakan oleh tetangga dan orang lain anaknya sekolah dimana ia perlu menjelaskan lebih, terlebih mertua juga selalu bertanya kenapa cucu kedua memiliki perilaku yang tidak sama dengan kakaknya. Padahal dukungan dari mertua sangat ia butuhkan, tetapi ia hanya bersabar semoga nanti bisa terbalaskan dengan anaknya yang dapat juga berprestasi seperti anak-anak yang lain. Menurut Subjek, ia memang harus siaga menjaga tingkah laku anak agar tidak sembarangan memegang barang, Subjek juga memberikan waktu dan energi yang lebih untuk menjaga anak keduanya karena jika lengah anaknya bisa keluar rumah dan bermain di rumah tetangga atau ke warung untuk mengambil beberapa mainan atau jajanan, ketika keinginannya tidak terpenuhi anak langsung menangis dan menjatuhkan diri ke tanah sampai ibu membelikan mainan atau jajan tersebut. Subjek mendapati skor 48 untuk parental stress scale dengan kategori sedang.

Subjek 3 (IN) Subjek ialah seorang ibu berusia 37 tahun yang memiliki anak berkebutuhan khusus. Anak berkebutuhan khusus ini ialah anak kedua yang berumur 7 tahun. Anak pertama Subjek normal seperti anak pada umumnya. Saat masa kehamilan Subjek sering meminum vitamin sampai dengan anaknya lahir. Saat balita anaknya terjatuh dari tempat tidur dan mengakibatkan luka dikepalanya, setelah itu Subjek merasa adanya perbedaan dari anak terlebih pada saat usia anak 3,5 tahun. Anak Subjek mengalami gangguan ADHD ringan. Subjek merasa anaknya ini tidak bisa diam, jika ada orang lain atau tamu datang ke rumah ia pasti naik ke atas meja atau loncat di kursi yang diduduki tamu, anak Subjek juga sering menghalangi motor yang lewat di depan rumah. Anak Subjek juga suka memukul tetapi memukulnya itu karena 
Subjek ingin bercanda dengan orang tersebut. Karena perilaku anaknya yang berbeda dari anak lainnya sehingga Subjek menyekolahkan di SLB.

Subjek merasa banyak pikiran setelah memiliki anak kedua, ia merasa sulit untuk menyamakan perlakuan antara kakak dan adik yang berbeda, ia juga tidak mau kakaknya merasa iri dengan adiknya. Subjek merasa kurang puas dengan pola asuh yang ia terapkan kepada anak karena kesulitan dalam mengatasi tingkah laku anak yang tidak bisa diam ia sering memberikan handphone kepada anak, sehingga muncul lagi beberapa permasalahan baru seperti anak malas belajar dan lebih suka memainkan handphone. Ia merasa kewalahan dalam menjaga anak dengan kebutuhan khusus. Sebenarnya ia merasa bahagia tetapi ia terkadang bertanya pada diri sendiri apakah ia betul-betul bahagia dan mampu merawat anak berkebutuhan khusus. Subjek mendapati skor 47 untuk parental stress scale dengan kategori sedang.

Subjek 4 (SU) Subjek ialah seorang ibu berusia 56 tahun yang memiliki anak berkebutuhan khusus. Anak berkebutuhan khusus ini ialah anak kedua. Anak pertama Subjek normal seperti anak pada umumnya. Pada masa kehamilan Subjek mengalami kenaikan pada tensinya, tensi Subjek saat itu ialah 200/110. Subjek melahirkan anak prematur saat usia 6 bulan didalam kandungan. Dokter mengatakan jika tidak dikeluarkan bayi yang ada dalam kandungan sangat beresiko sehingga dikeluarkan saat usia kandungan 6 bulan. Selama 4 bulan anak Subjek tersebut dimasukkan ke inkubator. Subjek saat 7 bulan didiagnosa dokter mengalami hidrosipalus dan dua kali operasi mata karena bola mata anak Subjek selalu bergerak-gerak.

Subjek mengatakan malu dan merasa tidak diterima dengan baik oleh lingkungan padahal ia tidak pernah berbuat buruk atau misalnya membicarakan anak tetangga dan sebaginya,ia juga merasa gagal mengapa ia sebagai ibu tidak bisa menjaga kesehatan dengan baik. Subjek selalu mengingat kejadian pada saat kehamilan dan juga melahirkan. Ia merasa setelah melahirkan ia tidak sepenuhnya bahagia karena bingung apa yang harus diperbuat untuk anaknya. Terkadang ada kekhawatiran yang sangat tinggi apakah Subjek dapat membesarkan anaknya, Subjek sangat pesimis takut jika sesuatu hal menimpa dirinya lalu siapa yang menjaga anaknya tersebut karena ia telah ditinggalkan oleh suami saat anak Subjek masih kecil. Ia harus berjuang untuk bertahan hidup agar dirinya dan anaknya dapat hidup dengan layak serta anaknya dapat meraih cita-cita. Subjek mendapati skor 53 untuk parental stress scale dengan kategori sedang.

Subjek 5 (RA) Subjek ialah seorang ibu berusia 42 tahun yang memiliki anak berkebutuhan khusus. Anak berkebutuhan khusus ini ialah anak kedua yang berusia 9 tahun. Anak pertama Subjek normal seperti anak pada umumnya. Subjek memiliki anak intellectual disabilitas ringan. Saat hamil Subjek mengalami pendarahan pada usia kandungan 3 bulan. Saat balita anak Subjek lamban dalam berjalan, dari merangkak menuju jalan memerlukan waktu yang lama. Saat taman kanak-kanak Subjek menyekolahkan anaknya di TK umum. Menurut Subjek anaknya yang lamban membaca, menulis dan belum mengenal mengenai pelajaran ialah hal yang wajar karena masih kecil. Saat tk besar guru tk mengatakan kepada Subjek jika anak Subjek kesulitan untuk belajar dan sulit dalam interaksi sosial. Subjek juga merasakan hal yang sama, Subjek lamban ketika diberi tahu atau diajarkan pelajaran.

Subjek merasa khawatir apakah selama ini yang ia lakukan belum cukup untuk perkembangan anak. Waktu Subjek juga dihabiskan lebih banyak dengan anak kedua daripada anak pertama karena Subjek merasa anak keduanya lebih memerlukan pendampingan khusus. Pada awalnya memang Subjek mengatakan bahwa ia malu karena guru di taman kanak-kanaknya selalu memanggil ke sekolah dan mengatakan bahwa Subjek berbeda dari anak yang lain. Terlebih ada beberapa orang tua murid yang lain yang mengajarkannya cara merawat anak yang memiliki kebutuhan khusus, terkadang memang nasihat yang baik akan ia turuti tetapi ada juga sebagian ibu-ibu yang terkesan menggurui karena merasa anaknya normal tidak seperti anak Subjek. Ia tidak pernah membandingkan anak orang lain tetapi ia merasa bahwa ia dan anaknya seperti tidak di terima di lingkungan tersebut karena anaknya berbeda dari anak yang 
lain. Maka dari itu saat memasuki SD Subjek memasukkan anaknya di SLB. Mempunyai anak berkebutuhan khusus membuat Subjek kehilangan minat untuk menambah anak, ada ketakutan jika anaknya akan mengalami gangguan yang sama seperti anak kedua. Subjek mendapati skor 48 untuk parental stress scale dengan kategori sedang.

Dapat ditarik kesimpulan bahwa kelima Subjek yang menjadi anggota kelompok memiliki beberapa kesamaan yaitu komentar negatif dari lingkungan lebih banyak memberi label negatif kepada masing-masing anggota kelompok. Selain itu ketidakmampuan menghadapi komentar negatif dari lingkungan membuat anggota kelompok mengalami perubahan yang signifikan terhadap hidupnya dan merasa bahwa dirinya yang paling tidak berdaya dan tidak dapat merawat anak dengan kebutuhan khusus. Terlebih anggota kelompok juga masih belajar menjadi ibu yang baik untuk anak berkebutuhan khusus mengingat anak pertama mereka ialah anak yang normal. Selain itu progres anak yang terbilang lamban dibandingkan anak normal membuat anggota kelompok memikirkan bagaimana masa depan anak kedepannya, apakah mereka sudah menjadi ibu yang baik dan bisa untuk menangani anak berkebutuhan khusus. Hal-hal seperti itu yang membuat pikiran para anggota semakin tidak tenang sehingga menimbulkan stress kepada masing-masing anggota kelompok.

Intervensi yang akan diberikan kepada anggota kelompok ialah konseling kelompok realitas. Glasser (1998) berpandangan bahwa semua manusia memiliki kebutuhan dasar fisiologis dan psikologis, perilaku manusia dimotivasi oleh dua kebutuhan tersebut. Kebutuhan yang dibutuhkan ialah kebutuhan akan love and belonging yaitu kebutuhan mengenai penerimaan dan cinta. Survival yaitu kebutuhan akan perjuangan atau bertahannya kelangsungan hidup seseorang. Power yaitu kebutuhan yang paling khusus pada seseorang yaitu keinginan berprestasi, kesuksesan, pengakuan dan ingin didengar. Freedom yaitu kebutuhan golden rule bahwa seseorang memperlakukan orang lain sebagaimana ia ingin diperlakukan dan Fun yaitu kebutuhan untuk bahagia. Dari kelima kebutuhan tersebut, jika tidak terpenuhi maka akan menimbulkan permasalahan bagi diri dan juga bisa berdampak bagi orang lain.

\section{Diagnosis dan Prognosis}

Hasil diagnosis Subjek memenuhi kriteria diagnostic and statistical manual of mental disorder fifth edition (DSM-5) (American Psychiatric Association, 2013) yaitu V15.89. Z91.89 yaitu other personal risk factor dengan permasalahan stress ibu yang memiliki anak berkebutuhan khusus.

Hasil keseluruhan prognosis pada kelompok ini adalah cukup baik. Anggota kelompok bersikap kooperatif, dapat diajak berkomunikasi dengan baik, dapat diarahkan untuk mengikuti konseling bersama. Konseling kelompok ini dilakukan atas dasar persetujuan seluruh anggota dan setiap Subjek memahami keseluruhan alur dalam intervensi. Maka dengan intervensi yang diberikan diharapkan semua Subjek untuk mengalami perubahan yang baik.

\section{Intervensi}

Dalam kasus ini intervensi yang digunakan adalah konseling kelompok dengan pendekatan konseling realita. Konseling kelompok dengan pendekatan realita memiliki fungsi terapi yang diwujudkan dalam kelompok kecil melalui pertukaran-pertukaran masalah pribadi antar anggota kelompok. Dengan adanya anggota lain dalam proses konseling ini maka masing-masing pratisipan dapat belajar dan bersama-sama mencari pemecahan terbaik di dalam menangani masalah. Target utama proses konseling adalah membantu anggota kelompok untuk menyadari kewajiban dan tanggung jawabnya sebagai seorang ibu pada masa sekarang dan masa yang akan datang tanpa memikirkan masa lalu mengenai gangguan anak.

Menurut Glasser (1998), konseling realitas mengajarkan orang untuk mendapatkan kendali efektif atas hidup mereka setelah mereka menyadari dan menerima tanggung jawab atas perilaku yang mereka pilih untuk diambil, dan kemudian membuat pilihan yang lebih baik setelahnya. 
Menurut Corey (2013), keuntungan yang diperoleh dari konseling realitas adalah jangka waktu konseling yang relatif pendek dan berurusan dengan masalah-masalah tingkah laku yang sadar. Konseli dihadapkan pada keharusan mengevaluasi tingkah lakunya dan membuat pertimbangan nilai. Pemahaman dan kesadaran tidak dipandang cukup, rencana tindakan dan komitmen untuk melaksanakannya dipandang sebagai inti terapeutik. Konseling realitas difokuskan pada tingkah laku sekarang dan merupakan bentuk modifikasi perilaku. Hal ini berfungsi agar konseli mampu membantu dirinya dalam menghadapi kenyataan dan memenuhi kebutuhan-kebutuhan dasar tanpa merugikan diri sendiri ataupun orang lain serta berani memikul tanggung jawab atas semua tingkah lakunya.

Tujuan umum konseling realitas adalah membantu seseorang untuk mencapai otonomi, yaitu kematangan yang diperlukan bagi kemampuan seseorang untuk mengganti dukungan lingkungan dengan dukungan internal (Palmer, 2013). Konseling realitas mencakup kejujuran dalam mengevaluasi perilaku saat ini, mengembangkan kesadaran pribadi, dan tentang membantu individu membuat rencana yang konkret untuk mengelola hubungan dengan orang lain yang mereka butuhkan dalam kehidupan mereka (Lopez, 2010). Dalam konseling pemahaman dan kesadaran tidak dipandang cukup, rencana tindakan dan komitmen untuk melaksanakannya dipandang sebagai inti terapeutik. Intervensi akan dilakukan dengan 6 sesi:

Sesi pertama merupakan sesi membangun raport. Praktikan memperkenalkan diri, mempersilahkan masing-masing anggota untuk memperkenalkan diri, menciptakan suasana kooperatif dan nyaman kepada anggota kelompok. Setelah itu dilakukan penjelasan mengenai peraturan dalam setiap sesi konseling, menjelaskan tentang kerahasiaan dan meminta setiap anggota untuk saling terbuka selama proses konseling kelompok. Seluruh Subjek sudah memahami bahwa tujuan dilaksanakannya konseling realitas ini adalah untuk membantu mereka menyadari dan menerima realita kehidupan dengan membuat pilihan dan saat mereka dapat bertanggung jawab menjalankan pilihan tersebut. Anggota kelompok juga dapat menjalin kedekatan dengan praktikan agar percaya dan dapat dengan mudah untuk bercerita. Sehingga Subjek menerima untuk menjalani sesi intervensi yang telah dirancang.

Sesi kedua yaitu membuat komitmen dan target. Seluruh subjek menyepakati peraturan yang ada pada konseling yaitu menjaga kerahasiaan semua Subjek dan terbuka atau menceritakan permasalahannya kepada kelompok. Setelah itu dilakukan penjelasan bahwa saat berlangsungnya sesi intervensi, masing-masing dari anggota kelompok untuk menceritakan permasalahannya. Dalam hal ini,para anggota diminta untuk aktif dan bergantian dalam bercerita. Pada tahap ini seluruh anggota bercerita mengenai permasalahan dan keluh kesah yang mereka rasakan. Sesi ini diakhiri dengan para anggota membuat jadwal untuk pertemuan selanjutnya dimana dalam proses tersebut terjalin keakraban satu sama lain. Hasilnya, masing-masing anggota kelompok mengungkapkan keinginan dan kebutuhan yaitu: masing-masing anggota kelompok ingin sukses merawat anak kedua mereka sehingga memiliki masa depan yang baik sama dengan anak pertama yang tidak berkebutuhan khusus, selain itu dapat diterima dengan baik oleh lingkungan sosial, dapat bertukar pikiran dengan orang lain dan dapat terus mendukung anak karena bukan hanya mereka saja yang memiliki permasalahan memiliki anak berkebutuhan khusus dan ingin melakukan sesuatu untuk anak agar anak mendapatkan pendidikan yang layak seperti anak yang lainnya.

Sesi ketiga adalah tahap kegiatan dan eksplorasi dengan teknik wants. Pada sesi ini ialah sesi untuk mendalami permasalahan kelima Subjek dan menanyakan apa saja yang mereka inginkan atau butuhkan saat ini. Sesi ini merupakan tahap eksplorasi masalah dengan WEDP, teknik W (Want), teknik D (directions and doing). Tujuan penggunaan teknik ini adalah mengeksplorasi kebutuhan dan apa saja tindakan yang sudah dilakukan oleh para anggota selama ini dalam menghadapi masalah mereka. Dengan menggunakan teknik want (W) yaitu dengan bertanya, "Apa yang kamu inginkan?" melalui pertanyaan ini, para anggota didorong 
untuk mengenali, menentukan, dan meningkatkan cara untuk memenuhi kebutuhan-kebutuhan mereka. Selanjutnya teknik doing yaitu menekankan sikap saat ini dan memperhatikan peristiwa-peristiwa saat ini.

Selanjutnya dilakukan eksplorasi tindakan dan pikiran anggota terhadap masalahnya dengan cara menanyakan apa saja yang telah dilakukan Subjek dan apa saja pikiran serta tindakan yang akan dipilih sekaligus dilakukan di kemudian hari guna mengatasi masalah yang dihadapi. Hal ini difokuskan pada masa sekarang ditandai dengan pertanyaan: "Apa yang sedang anda lakukan?". Masing-masing anggota diajak untuk perlu belajar bagaimana mengatasinya di masa sekarang dengan mempelajari cara yang lebih baik untuk mendapatkan apa yang mereka inginkan.

Hasil sesi ketiga masing-masing anggota diminta untuk memikirkan apa yang harus mereka lakukan untuk mendapatkan yang mereka inginkan. Masing - masing anggota kelompok juga bergantian memberikan pendapatnya terkait keinginan masing-masing anggota kelompok. Mereka dapat memberikan masukan, bertanya, menyanggah pemikiran negatif yang diucapkan oleh masing-masing anggota kelompok dan masing - masing anggota kelompok harus saling mengingatkan bahwa tujuan dilakukannya intervensi ialah untuk menurunkan stress, sehingga jika ada anggota kelompok yang kurang percaya diri dengan kemampuannya dalam menghadapi masalah, anggota kelompok dapat langsung menyanggah dan meyakinkan satu sama lain agar tidak memperparah tingkat stress yang dimiliki. Keinginan masing-masing anggota memang tidak jauh berbeda bahwa mereka selama ini jarang berinteraksi meskipun mereka sama-sama menunggu anak di sekolah. Masing - masing anggota diminta untuk bercerita mengenai hal-hal yang membuatnya merasa tidak berarti atau merasa kesulitan merawat anak kedua mereka. Dari hasil tanggapan masing-masing anggota diharapkan Subjek memiliki pandangan lebih mengenai hal-hal yang akan dilakukan sehingga Subjek dapat melihat dari sisi lainnya apakah yang ia lakukan nantinya akan berjalan dengan baik.

Sesi keempat, menggunakan teknik evaluation. Subjek dibantu untuk mengevaluasi dampak dari hasil perilaku yang selama ini Subjek miliki. Masing-masing anggota juga diminta untuk mengevalusi tindakan yang tidak bertanggung jawab saat ini, apakah merugikan atau tidak bagi Subjek. Tahap planning, membantu para anggota kelompok dalam mengidentifikasi cara-cara khusus untuk memenuhi keinginan dan kebutuhan mereka. Para anggota kelompok menentukan apa yang ingin mereka rubah, mereka umumnya siap untuk menunjukkan sikap lain yang mungkin dilakukan dan menjalankan rencana tindakan. Proses pembentukan dan pelaksanaan rencana membuat individu mampu untuk memiliki kontrol yang efektif terhadap hidupnya. Hasilnya ialah masing - masing anggota bercerita dan mengevaluasi rencananya masing-masing.

Sesi kelima merupakan evaluasi rencana. Evaluasi rencana yang telah diucapkan oleh seluruh subjek. Kemudian menanyakan sejauh mana masing-masing anggota kelompok mengetahui dan menerapkan rencana yang sudah ia ucapkan pada sesi sebelumnya. Subjek juga diminta untuk mengevaluasi kualitas tindakan-tindakan mereka dan membantu mereka untuk membuat pilihan yang efektif. Hasilnya ialah Masing-masing anggota kelompok sudah dapat berbaur dengan orang tua yang menunggu anaknya di SDLB. Sebelumnya mereka hanya berbicara seadanya, tidak pernah mengetahui permasalahan masing-masing dari anggota kelompok. Tidak hanya saling bertukar pikiran dengan anggota kelompok, tetapi juga dengan orang tua lain yang tidak bergabung dalam kelompok yang telah dibuat. Masing - masing anggota memiliki kesulitan masing - masing, seperti belum terbiasa saat harus berbicara mengenai permasalahan yang dialami. Terutama saat membawa anak berjalan ke tempat umum dan dilihat oleh orang lain, tetapi dengan planning yang sudah dibuat dan dengan dukungan dari teman satu kelompok, masing-masing anggota kelompok dapat dengan baik melewati planning yang telah ditentukan. Masing-masing anggota diminta untuk meneruskan planning yang telah 
dibuat dan meneruskan apa yang Subjek ingin lakukan untuk mengurangi tingkat stress pada diri mereka.

Sesi keenam Subjek bersama-sama mengevaluasi kembali rencana-rencana dari masing-masing. Subjek menanyakan kesulitan atau hambatan yang dialami, Subjek diberikan apresiasi atas keberhasilan mereka dan menyimpulkan hasil yang telah mereka capai. Masing-masing Subjek diminta untuk mengungkapkan kesan dan perkembangannya setelah menjalani seluruh rangkaian konseling. Setelah semua sesi dilaksanakan, maka diberi penjelasan pada semua anggota bahwa kegiatan konseling sudah dapat diakhiri, serta mengukur kembali dengan menggunakan parental stress scale dan subjective units of distress scale untuk masing-masing anggota kelompok. Setelah itu dilakukan Follow-up dengan menanyakan perkembangan perilakunya.

Hasil sesi keenam dilakukan evaluasi hasil dari intervensi masing-masing anggota kelompok. Masing-masing anggota kelompok menyadari bahwa mereka merasa lebih baik ketika dapat mengungkapkan apa yang mereka rasa berat saat menjalaninya. Selama ini mereka terlalu menutup diri dan merasa hanya permasalahan mereka sendiri saja yang paling berat, setelah diceritakan kepada orang lain mereka lebih merasa lega. Selain itu mereka juga memiliki planning yang baik untuk merawat anak mereka agar mendapatkan pendidikan yang lebih baik dan juga optimis untuk masa depan anak meskipun anak mereka berbeda dari kebanyakan anak yang lain.

\section{Hasil dan Pembahasan}

\section{Hasil}

Hasil intervensi pada kelima orang Subjek menunjukkan adanya perubahan pada parental stress scale menjadi lebih rendah dari hasil pre test. Perubahan hasil skor parental stress scale sebelum dan setelah konseling realitas dapat dilihat pada Gambar 1 dan Gambar 2.

Berdasarkan grafik perubahan skor, diketahui bahwa setiap Subjek mengalami penurunan tingkat stress setelah menjalani konseling kelompok realitas. Anggota kelompok menjadi lebih memahami masalah mereka terutama tentang pandangan negatif mereka terhadap diri sendiri, tidak menyalahkan diri sendiri dan para anggota tidak lagi merasa sebagai orang tua yang paling menderita karena menyadari bukan hanya diri mereka sendiri yang memiliki masalah ketika memiliki anak yang berkebutuhan khusus, dan yang terpenting ialah masing - masing anggota menyadari perilaku mereka selama ini tidak membantu dan justru menambah kesulitan untuk mereka, dan lebih optimis dalam melakukan perubahan yang lebih baik setelah menyadari

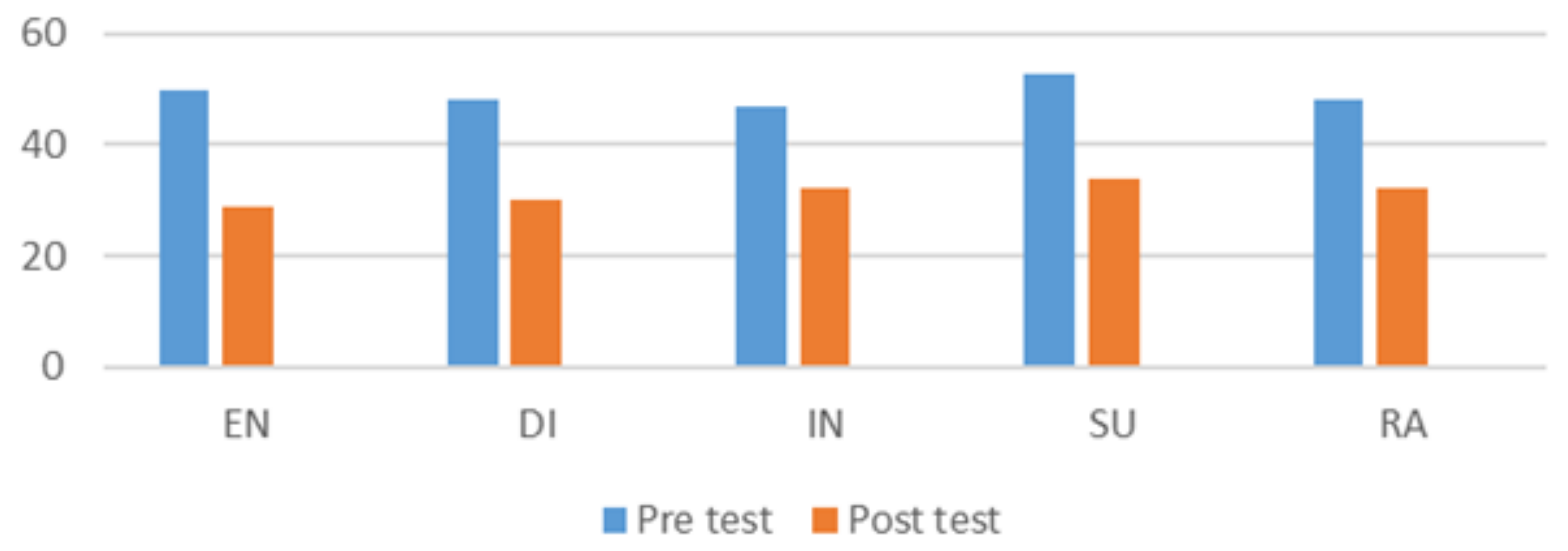

Gambar 1. Skor pre test dan post test parental stress scale. 


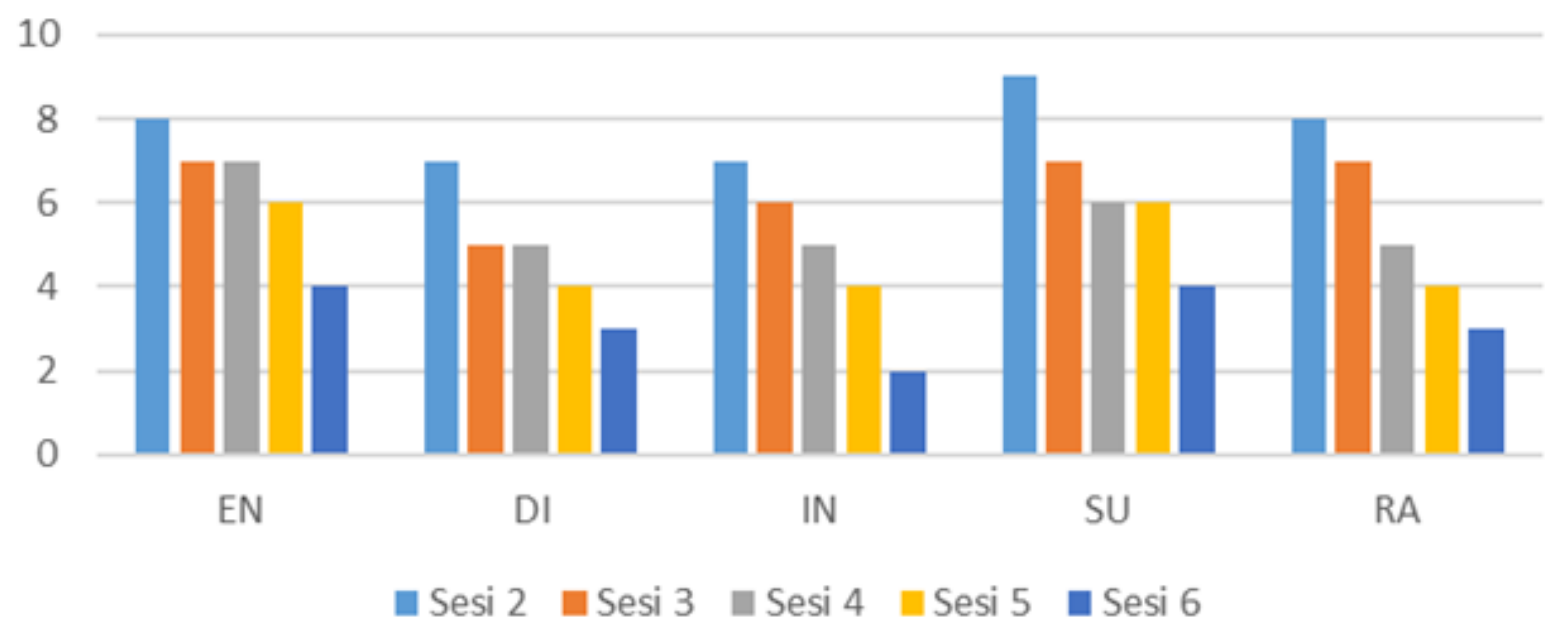

Gambar 2. Skor Subjective Units of Distress Scale.

sisi positif dalam diri mereka. Mereka juga berkomitmen untuk menerapkan rencana tindakan yang lebih bertanggung jawab untuk anak.

Selain itu masing - masing hasil SUDS dari angka 1 sampai dengan 10 dari anggota kelompok pada sesi kedua ialah Subjek EN memiliki tingkat stres di angka 8 dengan kategori stres tinggi. Subjek Di di angka 7 dengan kategori stres sedang, Subjek IN di angka 7 dengan kategori stres sedang, Subjek SU diangka 9 dengan kategori stres tinggi dan Subjek RA di angka 8 dengan kategori stres tinggi. Hasil SUDS dari angka 1 sampai dengan 10 dari anggota kelompok pada sesi ketiga ialah Subjek EN memiliki tingkat stres di angka 7 dengan kategori stres sedang. Subjek DI di angka 5 dengan kategori stres sedang, Subjek IN di angka 6 dengan kategori stres sedang, Subjek SU diangka 7 dan Subjek RA di angka 7 dengan kategori stres sedang.

Hasil sesi keempat dilakukan evaluasi terhadap planning yang diinginkan masing-masing anggota dan memastikan apakah planning tersebut tidak akan merugikan dan akan berhasil. Planning dari Subjek EN ialah Subjek ingin lebih sabar menghadapi perilaku anak, karena memiliki anak berkebutuhan khusus tentu berbeda dengan anak pertama sehingga ia ingin tidak mudah marah dan ia ingin dapat diterima dengan baik di lingkungan semisal saat membawa anaknya berbelanja di tempat umum. Ia akan mencoba terbuka dan menyadari bahwa anaknya berbeda dengan anak pada umumnya sehingga menerima ketika adanya orang lain yang belum paham mengenai kondisi anaknya dan lebih banyak berbaur dengan orang lain sehingga orang lain menjadi mengerti mengenai gangguan yang dialami oleh anak dan iapun tidak banyak pikiran lagi, hasil SUDS Subjek memiliki tingkat stres di angka 7 dengan kategori stres sedang. Planning dari Subjek DI ialah Subjek harus menyadari bahwa memang adanya perbedaan dengan anak pertama, sehingga ia membutuhkan tenaga lebih untuk menjaga anak. Ia juga mulai ingin berinteraksi dengan orang, semula ia merasa malu jika orang-orang mengetahui anaknya sekolah di SLB, ia tidak siap mendengar komentar dari tetangga. Ia mempunyai keinginan untuk dapat menjawab pertanyaan orang lain dengan baik sehingga orang lain dapat mengerti karena ia ingin dapat menyekolahkan anaknya dengan sekolah yang terbaik sama dengan anak-anak lainnya, hasil SUDS Subjek memiliki tingkat stres di angka 5 dengan kategori stres sedang.

Planning dari Subjek IN ialah Subjek dapat bertukar pikiran dengan orang tua murid yang sama-sama menunggu anaknya sekolah saat di SLB, karena selama ini ia merasa hanya dirinya yang merasa kesulitan menyeimbangi antara merawat anak normal dengan anak yang memiliki kebutuhan khusus sehingga ia selalu merasa terbebani dan merasa banyak pikiran karena tidak pernah mengetahui cerita dari orang lain yang juga memiliki permasalahan yang sama. Ia juga 
merasa pesimis anaknya dapat belajar dengan baik karena anaknya sudah memiliki kecanduan gadget, ia khawatir jika ini akan memperparah keadaan dan ia merasa bahwa ia salah dalam membebaskan anak untuk menggunakan gadget. Ia akan membuat perubahan yaitu memberikan permainan lain yang sesuai dengan usianya dan ia akan bertanya dengan orang tua murid yang mungkin memiliki anak yang juga senang memainkan gadget sehingga ia dapat masukan dan tidak merasa bahwa ia salah dalam merawat anak. Hasil SUDS Subjek memiliki tingkat stres di angka 5 dengan kategori stres sedang.

Planning dari Subjek SU ialah Subjek tidak ingin lagi menyalahkan diri sendiri atas apa yang telah terjadi. Ia juga ingin mempunyai teman yang dapat memberikannya semangat disaat ia merasa sendiri karena suami sudah lama meninggal. Ia merasa pesimis, dengan usia anak yang berusia 19 tahun, ia merasa sulit memikirkan anaknya akan bekerja apa nantinya. Sedangkan di rumah ia hanya tinggal berdua saja karena kakaknya sudah bekerja. Ia juga kesulitan untuk meninggalkan anaknya sendiri di rumah sehingga ia memiliki kekhawatiran yang cukup besar kepada anaknya. Ia juga ingin mengajari anaknya menjahit baju, sehingga nantinya ia berharap anaknya juga dapat bekerja seperti orang pada umumnya sehingga anak tidak merasa bahwa ia tidak berarti. Hasil SUDS Subjek memiliki tingkat stres di angka 6 dengan kategori stres sedang. Planning dari Subjek RA ialah ia ingin ia tidak terlalu khawatir dengan masa depan anaknya, ia harus yakin bahwa dengan menyekolahkan anak di SLB ia sudah melakukan yang terbaik. Ia juga akan bertukar pikiran jika ia merasa kebingungan saat menghadapi perilaku anak karena ia tau bahwa banyak ibu - ibu yang menunggu anaknya di sekolah yang memiliki anak lebih tua dari anaknya sehingga ia dapat belajar pengalaman yang telah dilewati oleh orang lain agar ia tidak merasa sendiri. Ia juga ingin membuang pikiran negatif yaitu tidak ingin lagi berfikiran bahwa ia tidak mau mempunyai anak lagi karena takut mendapatkan anak yang membutuhkan penanganan lebih. Hasil SUDS Subjek memiliki tingkat stres di angka 5 dengan kategori stres sedang.

Hasil sesi kelima masing-masing anggota diberikan pertanyaan mengenai penerapan dari hasil planning yang sudah ditentukan oleh masing-masing anggota kelompok. Hasil SUDS Subjek EN memiliki tingkat stres diangka 6 dengan kategori stres sedang. Subjek DI diangka 4 dengan kategori stres ringan. Subjek IN diangka 4 dengan kategori stres ringan. Subjek SU diangka 6 dengan kategori stres sedang dan Subjek RA diangka 4 dengan kategori stres ringan. Hasil SUDS pada follow up ialah Subjek EN memiliki tingkat stres diangka 4 dengan kategori stres ringan. Subjek DI diangka 3 dengan kategori stres ringan. Subjek IN diangka 2 dengan kategori stres ringan. Subjek SU diangka 4 dengan kategori stres ringan dan Subjek RA diangka 3 dengan kategori stres ringan. Perubahan pada subjek dapat dilihat pada Tabel 1.

\section{Pembahasan}

Hasil intervensi menggunakan konseling realitas dapat menurunkan tingkat stres yang dialami oleh ibu yang memiliki anak berkebutuhan khusus. Menurut Palmer (2013) Sesi evaluasi terhadap keinginan, persepsi dan perilaku memegang peran penting dalam perubahan pemahaman terhadap Subjek dalam menghadapi masalah menjadi lebih realistis. Evaluasi diri sendiri oleh Subjek merupakan inti terapi realitas dan mendapat penekanan terbesar dalam proses konseling. Dalam intervensi ini masing-masing anggota kelompok menyadari hal apa saja yang bisa memperkuat tingkat stres yang dimiliki terlebih cara mereka memandang bahwa hanya dirinyalah yang memiliki permasalahan yang berat membuat banyaknya pikiran yang menyebabkan stres selalu meningkat. Menurut Glasser (1998) terapi realitas mengajarkan orang untuk mendapatkan kendali efektif atas hidup mereka setelah mereka menyadari dan menerima tanggung jawab atas perilaku yang mereka pilih untuk diambil dan kemudian membuat pilihan yang lebih baik setelahnya. 
Tabel 1. Hasil intervensi konseling kelompok realitas

\begin{tabular}{|c|c|c|}
\hline No & Sebelum intervensi & Setelah intervensi \\
\hline 1 & $\begin{array}{l}\text { Anggota kelompok merasa stres karena } \\
\text { mempunyai banyak fikiran mengenai } \\
\text { pengasuhan anak berkebutuhan khusus } \\
\text { dan merasa belum sepenuhnya menjadi } \\
\text { ibu yang baik. }\end{array}$ & $\begin{array}{l}\text { Menurunnya tingkat stres karena } \\
\text { masing-masing anggota kelompok mampu } \\
\text { berbagi cerita dan mengapresiasi apa yang } \\
\text { telah ia lakukan untuk merawat anak dengan } \\
\text { kebutuhan khusus contohnya menyekolahkan } \\
\text { anak di sekolah luar biasa. }\end{array}$ \\
\hline 2 & $\begin{array}{l}\text { Anggota kelompok memandang diri } \\
\text { mereka paling menderita dan tidak } \\
\text { seberuntung orang tua lainnya }\end{array}$ & $\begin{array}{l}\text { Anggota kelompok tidak lagi merasa sebagai } \\
\text { orang tua yang paling menderita karena } \\
\text { menyadari bukan hanya diri mereka sendiri } \\
\text { yang memiliki permasalahan dengan anak } \\
\text { berkebutuhan khusus }\end{array}$ \\
\hline 3 & $\begin{array}{l}\text { Jarang berkomunikasi dengan orang lain. } \\
\text { Tidak bertukar pikiran dengan orang } \\
\text { tua lain yang saling menunggu anak di } \\
\text { sekolah }\end{array}$ & $\begin{array}{l}\text { Menyadari perilaku mereka selama ini tidak } \\
\text { membantu mengatasi masalah dan justru } \\
\text { menambah kesulitan untuk mereka. }\end{array}$ \\
\hline 4 & $\begin{array}{l}\text { Pesimis untuk mampu melakukan } \\
\text { perubahan perilaku karena menilai diri } \\
\text { mereka mampu untuk mendukung anak } \\
\text { memiliki masa depan yang baik }\end{array}$ & $\begin{array}{l}\text { Lebih optimis dalam melakukan perubahan } \\
\text { perilaku yang lebih baik setelah menyadari } \\
\text { sisi positif dalam diri mereka dan tanggung } \\
\text { jawab terhadap kehidupan mereka dengan } \\
\text { memiliki anak berkebutuhan khusus }\end{array}$ \\
\hline 5 & $\begin{array}{l}\text { Tidak memiliki komitmen dan rencana } \\
\text { tindakan yang konkret untuk melakukan } \\
\text { perubahan perilaku menjadi lebih baik. }\end{array}$ & $\begin{array}{l}\text { Berkomitmen untuk melakukan perubahan } \\
\text { dan memiliki rencana tindakan yang konkret } \\
\text { untuk melakukan perubahan dimulai dari hal } \\
\text { yang paling mudah yaitu saling bertukar } \\
\text { pikiran dengan sesama orang tua anak } \\
\text { berkebutuhan khusus. }\end{array}$ \\
\hline
\end{tabular}

Dari hasil akhir yang diapatkan bahwa skor dari parental stress scale yang menurun dan hasil subjective units of distress scale yang menunjukkan penurunan stress juga menjadi salah satu bukti adanya perubahan dari sebelum dilakukannya intervensi sampai dengan sesudah dilakukannya intervensi. Tidak semua anggota pada setiap sesinya mengalami penurunan pada tingkat stres yang diukur menggunakan subjective units of distress scale. Pada sesi ketiga Subjek EN dan DI tetap pada angka 7 yang berarti tidak terjadi penurunan stres. Pada sesi keempat SU juga tetap menuliskan angka 6 pada subjective units of distress scale padahal pada sesi keempat SU lumayan dapat bercerita dengan lancar dan mantap menyampaikan planning kedepannya tetapi hal itu tidak mempengaruhi nilai skala yang ia isi.

Menurut Corey (2013) keuntungan yang diperoleh dari konseling kelompok realitas ialah Subjek dihadapkan pada keharusan mengevaluasi tingkah lakunya dan membuat pertimbangan nilai. Pemahaman dan kesadaran tidak dipandang cukup, rencana tindakan dan komitmen untuk melaksanakannya dipandang sebagai inti terapeutik. Konseling kelompok realitas difokuskan pada tingkah laku sekarang dan merupakan bentuk modifikasi perilaku. Hal ini berfungsi agar Subjek mampu membantu dirinya dalam menghadapi kenyataan dan memenuhi kebutuhan-kebutuhan dasar tanpa merugikan diri sendiri ataupun orang lain serta berani memikul tanggung jawab atas semua tingkah lakunya. 


\section{Simpulan}

Dari hasil intervensi dapat diambil kesimpulan bahwa, konseling kelompok realitas mampu menurunkan tingkat stres ibu yang memiliki anak berkebutuhan khusus dengan cara meningkatkan kesadaran dan rasa tanggung jawab pada masing-masing anggota kelompok sehingga menyadari perilaku negatif yang muncul ketika Subjek hanya menyalahkan diri sendiri dan tidak melakukan perubahan yang berarti. Selama mengikuti proses intervensi ini, masing-masing anggota kelompok mulai menyadari dan memahami apa yang paling ia butuhkan pada masa sekarang. Keberhasilan intervensi juga tidak terlepas dari adanya motivasi internal dari diri Subjek untuk melakukan perubahan dan Subjekpun menyadari bahwa perbuatan yang ia lakukan jika tidak diubah akan berdampak negatif untuk dirinya. Perubahan yang terjadi pada Subjek menunjukkan peningkatan yang positif yang ditandai pada skor yang mengalami penurunan dalam parental stress scale dan subjective units of distress scale. Keinginan untuk berubah dari masing-masing anggota kelompok membuatnya berhasil menjalani intervensi.

Diharapkan masing-masing anggota kelompok tetap dapat bercerita dengan orang lain agar tidak merasa sendiri dalam menghadapi permasalahan. Saat bercerita dengan orang lain membuat kita mengetahui tingkat stres kita sampai pada tahap mana karena kita juga mendengar pengalaman orang lain dan mendapatkan saran juga dari orang lain. Masing masing anggota juga diharapkan bisa saling memberi semangat dan terus melakukan upaya agar anak mereka mendapatkan cita-citanya dan menjadi anak yang membanggakan orang tua. Jangan terlalu sering berfikir negatif ataupun selalu terpaku pada masa lalu, usahakan selalu memikirkan realitas yang ada dan apa yang ingin dilakukan kedepannya.

\section{Referensi}

American Psychiatric Association. (2013). Diagnostic and statistial manual (5th ed.) Washington, DC: American Psychiatric Publishing.

Berry, J. O., \& Jones, W. H. (1995). The parental stress scale: Initial psychometric evidence. Journal of Social and Personal Relationships, 12(3), 463-472. https://doi.org/10.1177/0265407595123009.

Bradley, E.L. (2014). Choice theory and reality therapy: An overview. International Journal of Choice Theory and Reality Therapy, 114 (1) 6-13.

Corey, G. (2013). Theory and prctice of group counseling (5th edition). Pacific Group, CA:Brooks/Cole Publishing.

Farmani, F., Taghavi, H., Fatemi, A., \& Safavi, S. (2015). The efficacy of group reality therapy on reducing stress, anxiety and depression in patients with Multiple Sclerosis (MS). International Journal of Applied Behavioral Sciences, 2(4), 33-38. https://doi.org/10.22037/IJABS.V2I4.11421.

Glasser, W. (1998). Choice theory: A new psychology for personal freedom. New York: Harper Collins.

Lopez, I.P. (2010). Choices and responsibility in counseling: Looking into neuro linguistic programming (NLP) and reality therapy (RT) for a common thread. International Journal of Choice Theory and Reality Therapy, 30 (2), 23-35.

Martin, C., \& Colbert, K. (1997). Parenting: a life span perspective. New York: McGraw-Hill.

Palmer, S. (2011). Konseling dan psikoterapi. Yogyakarta: Pustaka Pelajar

Ritzema, A. M., \& Sladeczek, I. E. (2011). Stress in parents of children with developmental disabilities over time. Journal on Developmental Disabilities, 17(2), 21-34. 